\title{
Commercialization as a Tool for the Conservation of Environmental Resources
}

\author{
*ADELEKE, BO; OGUNSUSI, K \\ Department of Transport and Tourism Studies, Redeemer's University, Ede, Nigeria \\ *Corresponding Author Emil: adelekeb@run.edu.ng
}

\begin{abstract}
The primary objective of the paper is to report the survey of environmental resources conducted in Ode-Irele forest using two staged technique. This study was framed within the model that sustainable management of environmental resources is a consequence of heavy reliance on subsistence extraction of resources. Data were analysed using descriptive statistics of frequency counts and percentages. The result reveals that $65 \%$ of the respondents hunted wild animals for food, $62 \%$ also traded in wild animals and their products, $69 \%$ traded in natural honey, and $86 \%$ also traded in medicinal plants. $92 \%$ of respondents were involved in collecting wood for use and sale, while $92 \%$ were also involved in trade in wild fruits. Most of the respondents, who hunted animals for food, traded in wild animals and their products, natural honey, medicinal plants, wild fruits and those who also collected firewood for use and sale also conserved trees on their farms for the continued availability of the resources. Sustainable use of environmental resources by local residents in natural forested areas could only be achieved if they realize that continued availability of the resources is dependent upon the wise use and most importantly the conservation of the resources.
\end{abstract}

\section{DOI: https://dx.doi.org/10.4314/jasem.v22i5.25}

Copyright: Copyright $@ 2018$ Adeleke and Ogunsusi. This is an open access article distributed under the Creative Commons Attribution License (CCL), which permits unrestricted use, distribution, and reproduction in any medium, provided the original work is properly cited.

Dates: Received: 04 April 2018; Revised: 22 April: 2018; Accepted: 24 April 2018

Keywords: Conservation, Environmental resources, Management, Sustainable

The conservation of natural resources especially nontimber forest products (NTFPs) in privately owned lands can be used for sustained economic development, wealth creation and alleviation of poverty especially in the rural communities in tropical forests (Olaniyi et al., 2013; Farinola et al., 2014; Lindsey and Madigosky, 2014; Roberto et al., 2014; Dhakal, 2016). Use of NTFPs is not limited to commercialization because gathering and utilization of NTFPs has also been used for scientific investigations (Keca et al., 2013). The tropical rural dwellers exploit their basic needs from the fragile ecological resource base of the forests (Singwane and Shabangu, 2012). Forest, trees and associated environmental resources are becoming scarce, thus resulting in a state of imbalance between what rural households need and what they can obtain. This poses a threat to sustainable use and management of forest resources (Oyekale and Ajesi, 2011). Rural households should therefore involve themselves in the management of forest areas in order to be able to obtain a number of products from them. Indigenous knowledge about marketable NTFPs can be exploited as a means for sustainable forest management in local communities (Farinola et al., 2014). Involvement of rural farmers in tree plantations is a potential tool for reducing the degradation of natural forests and sustainable management of wildlife populations (Meijaard et al., 2006; Pirard et al., 2016). NTFPs are important in local, national and international markets especially when they are sustainably and continuously available. But, information on these resources, their harvests, methods of processing and trade is scarce and dispersed (Lintu, 1986). For this purpose the study focused on assessing the commercial uses to which environmental resources are put by rural communities and the management efforts geared towards sustainable utilization and conservation of the environmental resources.

\section{MATERIALS AND METHODS}

Study Site: The presence of bitumen outcrops in different sites of southwestern Nigeria which included Ilubirin, Agbabu, Loda, and Ode-Irele have been widely reported (Lameed and Ogunsusi, 2002a; Lameed and Ogunsusi, 2002b; Onojake et al., 2016). The study was conducted in the forested bitumen exploration belt of Ode-Irele, Ondo State, Nigeria. The bitumen discovered in Nigeria spread across four states which are Lagos, Ogun, Ondo, and Edo states. The bitumen occurred in abundance in some local governments of Ondo State out of which Irele's bitumen has been classified to have better characteristics with extra heavy oil (Onajake and Ndubuka, 2016). Irele is located in the Southern fringe of the state between Longitudes $04^{0} 47^{1} \mathrm{E}$ to $05^{0} 10^{1} \mathrm{E}$, and Latitudes $06^{0} 16^{1} \mathrm{~N}$ to $06^{0} 40^{1} \mathrm{~N}$. The area falls within the tropical rainforest ecological zone.

Sample and Sampling Technique: Two staged sampling technique was adopted with enumeration area being the first stage and the respondents were regarded as the second stage. Ten enumeration areas within the forest area were selected based on simple random sampling technique. The respondents were 
selected within households which were the basic unit of data collection. The headship of households and any other one person above the age of 18 years were selected as respondents. A total of 100 households were selected with ten from each enumeration area. In each selected households, questionnaires were administered to two persons. 200 copies of questionnaires were administered in each of the enumeration areas. A total number of 2,000 questionnaires were administered with less than five percent returned unattended to. Specially trained interviewers with fluency in local language were used for conducting surveys among the local communities. The basic information at the respondent level included questions about the respondent's sex, age, educational status, residence of parents, previous residence, property owned, size of land, time land was acquired, payment of rent. Direct economic uses of the forest were ascertained by asking the respondent about the satisfaction derived from using environmental resources. Questions were also asked about the management of trees for some environmental resources. This study was framed within the model that sustainable management of environmental resources is a consequence of heavy reliance on subsistence extraction of resources.

Data Analysis: Data were analysed using SPSS and Minitab computer packages. Findings on the variables were analysed using descriptive statistics, frequency counts, percentages and cross tabulations. Qualitative descriptive analysis was used to verbally summarize information on demographic profile.

\section{RESULTS AND DISCUSSION}

Socio-demographic features: This study has revealed highest demographic proportion of male residents, illiterate persons, people whose parents are resident in the locality and those who are themselves resident in the locality. Data on gender demography showed that the majority of the sample households in the study area were male-headed, which agreed with the findings of German et al., (2009), Mbavai et al., (2015) and Oeba et al., (2012). Result on educational level, however, contrasts with the finding of Kobbail (2012) in which significant relation between respondents' educational level and attitudes towards participation in forest management was reported. Length of residence in a rural setting could also be linked to resource exploitation and management for sustainable use (Nyamasyo and Kihima, 2014). Results have also shown that those within the age brackets of 21-30 years and $41-50$ years constituted $50 \%$ of respondents in the study population. This age grades are the most active in terms of agility to work as reported in the findings of Mbavai et al., (2015) and Nyamasyo and Kihima (2014). On property ownership, the result depicts a noticeable increase in property ownership that tended towards owning farm, house for settlement and land for farming and settlement which are of prime importance to the people of the study area. This is supported by the findings of (Nyamasyo and Kihima, 2014). The result on time period of land acquisition revealed that respondents that have lived in the study area since birth have the largest share of property. This could be attributed to the strong ties that they have with the land since birth, which agrees with the finding of Nyamasyo and Kihima (2014) on length of residence.

Commercial Values of Environmental Resources: Higher proportion of the respondents hunted wild animals for food and also traded in the wild animals as well as their products which agreed with the finding of Larsen (2003) and Nijman (2010). The higher proportion of people involved in hunting wild animals for food and who also traded in the wild animals and their products was manifested in the higher proportion of people who were also involved in conservation of trees. Therefore, hunting of wild animals and trade in them and their products can be exploited for creating empathy towards wildlife in forested areas as reported in the findings of Nijman (2010) and Meijaard et al., (2006) . Trade in Natural Resources and Conservation of Environmental Resources: Higher proportion of the respondents traded in natural honey and medicinal plants as well as conserve trees. The potential of honey from wild bees in natural forest to alleviate poverty in rural areas has variously been highlighted (Muli et al., 2015; Fikir et al., 2016; Amulen et al., 2017). Also, the growing interest in the use of medicinal plants and trade in them has variously been highlighted by a number of researchers (Moeng and Potgieter, 2011; Street and Prinsloo, 2013). The honey and medicinal plants which are mostly derived from communal lands in natural forest areas is very crucial in meeting health needs as well as being a source of income to rural dwellers. Residents' Involvement in Collection of Resources and Conservation: Higher proportion of the respondents collected wood for use and sale and also traded in wild fruits as well as conserve trees. Gathering of wood for making fire domestically as well as for sale and also trade in wild fruits has long been used as a means of livelihood by people residing close to natural forest areas. So also have people been involved in trade for varieties of wild fruits as a means of life sustenance and rejuvenation of local economy (Keca et al., 2013; Olaniyi et al., 2013; Farinola et al., 2014).

Conclusion: Utilization of forest products in the form of hunting and trade in wildlife products, natural honey, medicinal plants, wild fruits, and collection of wood for use and sale among others are tools that can be used not only to secure food and alleviate poverty in rural communities, but, also to conserve biodiversity. Utilization of environmental resources can be exploited for creating empathy towards biodiversity in forested areas. The emphasis will now be on tree and vegetation conservation as techniques for sustainably managing wildlife populations. 
Table 1. Hunting and Trade in Wild Animals Cross Tabulated with Management and Conservation of Environmental Resources

\begin{tabular}{|c|c|c|c|c|c|c|}
\hline $\begin{array}{l}\text { People } \\
\text { huntin }\end{array}$ & $\begin{array}{l}\text { invo } \\
\text { nals fo }\end{array}$ & & $\begin{array}{l}\text { People are involved in trade in } \\
\text { wild animals and their products }\end{array}$ & $\begin{array}{l}\text { Total } \\
\text { wild }\end{array}$ & $\begin{array}{l}\text { hunting } \\
\text { mals for }\end{array}$ & $\begin{array}{l}\text { Total for trade in } \\
\text { wild animals and }\end{array}$ \\
\hline Conser & $n$ of $\operatorname{tr}$ & for $\mathrm{t}$ & ber and arable crops & food & & \\
\hline & Yes & No & Yes & No & & \\
\hline Yes & 58 & 7 & 56 & 6 & 65 & 62 \\
\hline No & 34 & 1 & 36 & 2 & 35 & 38 \\
\hline Total & 92 & 8 & 92 & 8 & 100 & 100 \\
\hline Conser & $\mathrm{n}$ of $\mathrm{tr}$ & for a & mals food & & & \\
\hline & Yes & No & Yes & No & & \\
\hline Yes & 34 & 31 & 32 & 30 & 65 & 62 \\
\hline No & 8 & 27 & 10 & 28 & 35 & 38 \\
\hline Total & 42 & 58 & 42 & 58 & 100 & 100 \\
\hline Conser & $n$ of $\operatorname{tr}$ & for $\mathrm{s}$ & de for animals/understorey crops & & & \\
\hline & Yes & No & Yes & No & & \\
\hline Yes & 58 & 7 & 55 & 7 & 65 & 62 \\
\hline No & 34 & 1 & 37 & 1 & 35 & 38 \\
\hline Total & 92 & 8 & 92 & 8 & 100 & 100 \\
\hline Conser & n of $t_{1}$ & for $\mathrm{s}$ & conservation & & & \\
\hline & Yes & No & Yes & No & & \\
\hline Yes & 50 & 15 & 47 & 15 & 65 & 62 \\
\hline No & 33 & 2 & 36 & 2 & 35 & 38 \\
\hline Total & 83 & 17 & 83 & 17 & 100 & 100 \\
\hline
\end{tabular}

Table 2. Trade in Natural Honey and Medicinal Plants Cross Tabulated with Conservation of Environmental Resources

\begin{tabular}{|c|c|c|c|c|c|c|}
\hline \multicolumn{5}{|c|}{$\begin{array}{l}\text { People are involved in trade in Peop } \\
\text { natural honey } \\
\text { medi } \\
\text { Conservation of trees for timber and arable }\end{array}$} & \multirow{2}{*}{$\begin{array}{l}\text { Total for trade } \\
\text { in natural } \\
\text { honey } \\
\text { Yes }\end{array}$} & \multirow{2}{*}{$\begin{array}{l}\text { Total for trade in } \\
\text { medicinal plants } \\
\text { No }\end{array}$} \\
\hline \multicolumn{2}{|r|}{ Yes } & No & Yes & \multirow{2}{*}{$\begin{array}{l}\text { No } \\
4\end{array}$} & & \\
\hline Yes & 62 & 7 & 82 & & 69 & 86 \\
\hline No & 30 & 1 & 10 & 4 & 31 & 14 \\
\hline \multirow[t]{3}{*}{ Total } & 92 & 8 & 92 & 8 & 100 & 100 \\
\hline & \multicolumn{4}{|c|}{ Conservation of trees for animals food } & & \\
\hline & Yes & No & Yes & No & Yes & No \\
\hline Yes & 34 & 35 & 38 & 48 & 69 & 86 \\
\hline No & 8 & 23 & 4 & 10 & 31 & 14 \\
\hline \multirow[t]{3}{*}{ Total } & 42 & 58 & 42 & 58 & 100 & 100 \\
\hline & \multicolumn{5}{|c|}{ Conservation of trees for soil conservation } & \\
\hline & Yes & No & Yes & No & Yes & No \\
\hline Yes & 57 & 12 & 72 & 14 & 69 & 86 \\
\hline No & 26 & 5 & 11 & 3 & 31 & 14 \\
\hline Total & 83 & 17 & 83 & 17 & 100 & 100 \\
\hline
\end{tabular}

Table 3. Collection of Wood for Use and Sale, and Trade in Wild Fruits Cross Tabulated with Conservation of Environmental Resources

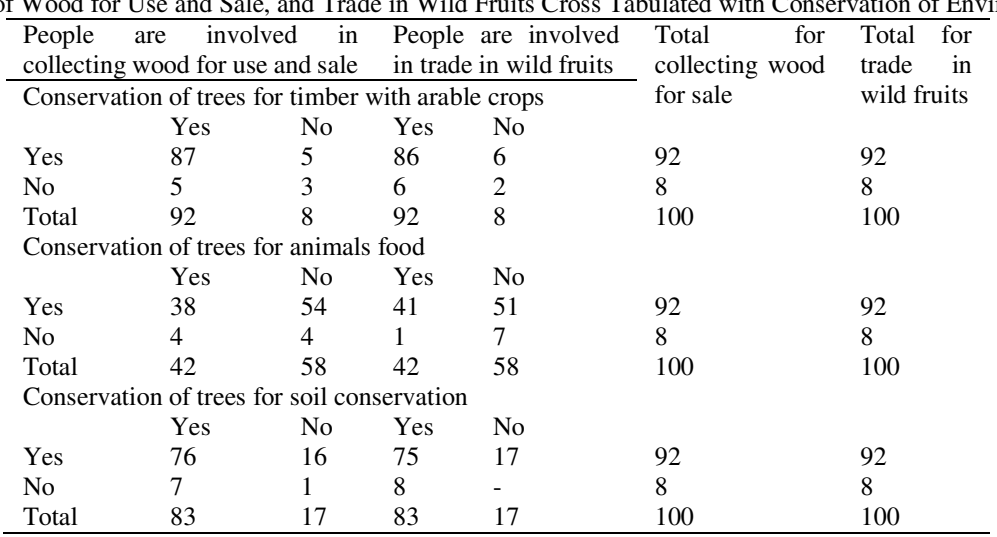

\section{REFERENCES}

Farinola, LA; Famuyide, OO; Nosiru, MO; Ogunsola, AJ (2014). Survey of Identified Non-Timber Forest Products and Their Role in the Rural Livelihood of Inhabitants of Omo Forest Reserve, Ogun State. Int. Journal of Agric. and For. 4(4): 317-324, DOI: 10.5923/j.ijaf.20140404.09
Fikir, D; Tadesse, W; Gure, A (2016). Economic Contribution to Local Livelihoods and Households Dependency on Dry Land Forest Products in Hammer District, Southeastern Ethiopia. Int. Journal of For. Res. Article ID 5474680, 11 pages. http://dx.doi.org/10.1155/2016/5474680 
Keca, LJ; Keca, N; Rekola, M (2013). Value Chains of Serbian Non-Wood Forest Products. Int. For. Rev. 15(3): 315-335. doi: http://dx.doi.org/10.1505/146554813807700164

Kobbail, AR (2012). Local People Attitudes towards Community Forestry Practices: A Case Study of Kosti Province-Central Sudan. Int. Journal of For. Res. Article ID 652693, http://dx.doi.org/10.1155/2012/652693

Lamed, GA; Ogunsusi, K (2002a). Environmental Impact Assessment of Bitumen Exploitation on Animal Resources of Ode-Irele Forest Area. African Journal of Livestock Extension. 1:15-21. http://www.ajol.info/index.php/ajlex/article/view/106 Retrieved 04/11/2017

Lamed, GA; Ogunsusi, K (2002b): The Relationship between Vegetation and Fauna Resources under Bitumen Exploitation in Ode-Irele Forest Area of Ondo State, Nigeria. Journal of Tropical Forest Resources. 16: $46-52$.

Lindsey, S; Madigosky, SR (2014): Environmental Perceptions and Resource Use in Rural Communities of the Peruvian Amazon (Iquitos and vicinity, Maynas Province). Tropical Conservation Science. 7(3): 382402.

Lintu, L (1986). Trade and Marketing of Non-wood Forest Products. In International Expert Consultation on NonWood Forest Products. FAO Forestry Department. http://www.fao.org/docrep/v7540e/V7540e19.htm, Retrieved 09/04/2017

Mbavai, JJ; Shitu, MB; Abdoulaye, T; Kamara, AY; Kamara, SM (2015): Pattern of Adoption and Constraints to Adoption of Improved Cowpea Varieties in the Sudan Savanna Zone of Northern Nigeria. Journal of Agric. Ext. and Rur. Dev. 7(12): 322-329.

Meijaard, ED; Sheil, R; Nasi, M; Stanley, SA (2006). Wildlife Conservation in Bornean Timber Concessions. Ecology and Society. 11(1): 47. [online] URL: http://www.ecologyandsociety.org/vol11/iss1/art47/

Moeng, ET; Potgieter MJ (2011). The Trade of Medicinal Plants by Muthi Shops and Street Vendors in the Limpopo Province, South Africa. Journal of Medicinal Plants Research. 5(4): 558-564.

Muli, E; Patch, H; Frazier, M; Frazier, J; Torto, B; Baumgarten, T (2014). Evaluation of the Distribution and Impacts of Parasites, Pathogens, and Pesticides on Honey Bee (Apis mellifera) Populations in East Africa. PLoS ONE, 9(4) https://doi.org/10.1371/journal.pone.0094459

Nijman, V. (2010). An Overview of International Wildlife Trade from Southeast Asia. Biodiversity and Conservation. 19(4):1101-1114 http://link.springer.com/article/10.1007/s10531-009$\underline{9758-4}$
Nyamasyo, SK; Kihima, BO (2014): Changing Land Use Patterns and Their Impacts on Wild Ungulates in Kimana Wetland Ecosystem, Kenya. International Journal of Biodiversity. http://dx.doi.org/10.1155/2014/486727

Oeba, VO; Otor, SCJ; Kung'u, JB; Muchiri, MN (2012). Modelling Determinants of Tree Planting and Retention on Farm for Improvement of Forest Cover in Central Kenya. ISRN Forestry, Article ID 867249, 14 pages. http://dx.doi.org/10.5402/2012/867249

Olaniyi, OA; Akintonde, J; Adetumbi, SI (2013). Contribution of Non-Timber Forest Products to Household Food Security among Rural Women in Iseyin Local Government Area of Oyo State, Nigeria. Research on Humanities and Social Sciences. 3(7): 5667.

Onojake, MC; Osuji, LC; Ndubuka, CO (2016). Characterization of Bitumen Samples from Four Deposits in Southwest, Nigeria Using Trace Metals. Egyptian Journal of Petroleum. 6 pages. http://dx.doi.org/10.1016/j.ejpe.2016.08.002

Oyekale, AS; Ajesi, DO (2011). Households' Exploitation of Non-Wood Forest Products (NWFPs) in Okitipupa Local Government Area of Ondo State, Nig. Journal of Hort. and For. 3(7): 222-225, http://www.academicjournals.org/jhf

Pearce, DW (2001). The Economic Value of Forest Ecosystems. Ecosystem Health. 7(4): 19-27.

Pirard, R; Secco, LD; Russell, WR (2016). Do Timber Plantations Contribute To Forest Conservation? Environmental Science \& Policy. 57(1): 122-130 http://www.sciencedirect.com/science/article/pii/S146 $\underline{2901115301271}$

Roberto, P; Alejandro, L; Lourdes, Q; Zully, PS; Miguel, V; Clemente, S; VladimirI, N; Jefferson, C (2014). Forest Use and Agriculture in Ucayali, Peruvian Amazon: Interactions among Livelihood Strategies, Income and Environmental Outcomes. Tropics. 23(2): 47-62.

Singwane, SS; Shabangu, N (2012). An Examination of the Utilization and Management of Natural Woodlands in Swaziland - A Case of Ka Bhudla Community. Journal of Sust. Dev. in Afri. 14(1): 34-45.

Street, RA; Prinsloo, G (2013). Commercially Important Medicinal Plants of South Africa: A Review. Journal of Chemistry. http://dx.doi.org/10.1155/2013/205048 